\title{
Kasus Gempa Bumi di Yogya dan Jawa Tengah: Perspektif "Supply Chain Management", Komunikasi, dan Kultural
}

\begin{abstract}
Santi Indra Astuti
ABSTRACT

May 27th 2006, a-5.9-Richter scale-of-earthquake is collapsing Jogja and its surrounding. More than 5.800 inhabitants dead, hundreds of thousands other were injured. The city collapsed, along with its economy which suffered at least 8-billion-rupiahs-loss. Days after the earthquake, there were complaints everywhere concerning the system of logistic supply for the victims. The lack of food, unreachable locations, the slow treatment of injured victims were seen everywhere. From communication perspective, these complaints marked the lack of quality in communication system as main part of post-disaster-management. To overcome such problems, the local government in disaster area must build SCM - supply chain management-as the approach to communication-management system in order to distribute logistics for the victims. SCM consisted of three elements: supply chain network, supply chain process, and supply chain management. Although based on management approach, SCM covered comprehensive issues such as the importance of data, research, goals identification, transportation facilities, along with moral, attitude, and cultural sensitivity.
\end{abstract}

Kata kunci: Supply-chain-management, krisis, bencana, sistem komunikasi

\begin{abstract}
Aneka permasalahan muncul dalam penyaluran bantuan bagi korban gempa di Daerah Istimewa Yogyakarta (DIY) dan Jawa Tengah. Jumlah bantuan yang berhasil dikumpulkan dalam pekan pertama pascagempa adalah sebesar 120 milyar rupiah. Namun, hingga seminggu pascagempa, masih banyak daerah yang belum tersentuh bantuan. Padahal, Yogya dan Jawa Tengah tak seperti Aceh, yang letaknya jauh dari pusat kekuasaan. Bahkan, gempa Yogya dan Jawa Tengah mendapatkan perhatian yang sangat istimewa: tak kurang dari Presiden RI sendiri memindahkan kantornya dari Jakarta ke Yogya sehari setelah gempa. Kendati pun demikian, kehadiran beliau tampak tak banyak berpengaruh
\end{abstract}

bagi penanganan korban gempa. Penyaluran bantuan tetap saja tersendat-sendat-sebuah fakta yang sangat bertentangan dengan media massa yang melaporkan peningkatan akumulasi bantuan dari anggota masyarakat setiap haribahkan setiap jam! Apa yang terjadi? Di mana letak simpul kemacetan ini? Pada sistem informasi-kah? Atau pada krisis implementasi di lapangan?

Tulisan berikut bermaksud menelusuri, dan menginventarisasi, sejumlah kemungkinan akar permasalahan yang terjadi dalam penanganan korban pascagempa di Yogya dan DIY. Dimulai dengan pemaparan fakta bencana, masalah yang terjadi di lapangan, berikut pembahasannya, penulis berharap dapat memberikan rekomendasi 
dan solusi bagi langkah-langkah penanganan bencana yang berbasis pada pendekatan supply chain management (SCM) yang disemangati oleh civic management system.

\section{Fakta Bencana dan Pascagempa}

Pada tanggal 27 Mei 2006, pukul 5.50 WIB, terjadi gempa 5,9 Skala Richter di DIY dan Jawa Tengah. Episenter gempa terletak sekitar 6 kilometer dai tepi pantai, di kedalaman 35 kilometer Laut Selatan. Gempa ini mengguncang kawasan pantai Parangtritis, Baron, Samas, Glagah, Wonosari, Gunung Kidul yang terletak di ring 1, disusul Kabupaten Bantul, Kulon Progo, dan Klaten di ring 2. Wilayah DIY lainnya juga terguncang, mulai dari kawasan Kraton, Sapen, sampai Kaliuranggempa bahkan terasa hingga ke kawasan Purwokerto, Magelang, dan Purbalingga, Jawa Tengah.

Di DIY, kawasan yang rusak parah bukan di ring 1, melainkan di Kabupaten Bantul yang terletak di ring 2, dengan konsentrasi kerugian terbesar di Kecamatan Bambanglipuro, disusul Imogiri, Pleret, Piyungan, dan Sewon. Struktur tanah alluvial menyebabkan Kabupaten Bantul ancur-ancuran dilanda gempa. Secara keseluruhan, gempa mengakibatkan lebih dari 5.800 jiwa tewas, 120 ribuan bangunan hancur, dengan potensi kerugian ekonomi mencapai lebih dari 8 trilyun rupiah.

Kondisi ini segera ditanggapi oleh pemerintah dengan kecepatan bertindak melebihi penanganan pascabencana tsunami di Aceh, pada penghujung 2004 silam. Presiden RI Susilo Bambang Yudhoyono memindahkan kabinet pemerintahannya ke Yogya, dan berkantor selama 5 (hari) di sana untuk mengendalikan Satuan Koordinasi Pelaksana (Satkorlak) guna memastikan keberesan penanganan korban pascagempa. Sementara itu, aksi solidaritas penggalangan dana dilakukan di mana-mana, oleh siapa saja. Metro TV dalam waktu sehari berhasil mengumpulkan dana sebesar Rp 4 milyar rupiah. Pemerintah sendiri diberitakan langsung mengucurkan dana tanggap darurat sebesar Rp 2 milyar rupiah melalui Dinas Kesejahteraan Sosial, yang dialokasikan melalui Satkorlak.
Kendati demikian, fakta lapangan memperlihatkan, penanganan korban pascagempa tidak berlangsung dengan baik. Pada hari pertama, praktis korban tidak mendapatkan upaya penanganan apa pun, kecuali korban cedera yang berada di rumah sakit ataupun posko-posko kesehatan seperti puskesmas. Itu pun, penanganan yang seadanya karena semua lokasi pelayanan kesehatan, baik rumah sakit besar maupun puskesmas, kewalahan menangani korban yang ribuan jumlahnya. RS Panti Rini di wilayah Kalasan, misalnya, yang memiliki kapasitas tak lebih dari 60 bed, pascagempa didatangi tak kurang dari 600-an korban dari wilayah Klaten dan Prambanan dengan kondisi cedera berat sampai ringan. Maka, bayangkan saja rumah sakit di wilayah Bantul! RS PKU Muhammadiyah, yang memiliki kapasitas 140 bed, harus menangani 2000-an pasien dengan kondisi sebagian besar luka berat! Yang lebih memprihatinkan, penanganan pasien terpaksa dilakukan dalam kondisi bangunan RS yang rusak akibat gempa, di tengah teror gempa susulan yang frekuensi dan skalanya masih cukup tinggi.

Hingga seminggu pascagempa, berita di koran masih saja memperlihatkan adanya kantongkantong wilayah yang belum tersentuh bantuan. Ini terutama diderita di desa-desa kawasan Gunung Kidul dan Kulon Progo, serta di wilayah-wilayah pelosok Klaten seperti Gantiwarno. Sulit dipercaya, di kawasan seperti Yogyakarta, masih ada saja tempat-tempat yang tak tersentuh oleh 'dunia luar'. Namun, begitulah memang keadaannya.

Kini, empatpuluh hari pascagempa, bahkan setelah 'jadup' alias, living cost dikucurkan oleh pemerintah, masih saja terjadi kericuhan. Kalau sebelumnya isu seputar bantuan berkisar pada penyaluran bantuan yang tidak merata, kini setelah 'jadup' turun, persoalan beralih pada maraknya demonstrasi terjadi, akibat pembagian living cost yang tidak merata. Tidak merata di sini bisa berarti dua hal: tidak mendapatkan jadup sementara wilayah lain mendapatkannya, sebagaimana terjadi di Kecamatan Berbah dan Bugisan (Kalasan); atau mendapatkan jadup namun jumlahnya lebih sedikit, tidak sesuai dengan yang semestinya-kasus korupsi yang memedihkan hati ini terjadi di 
beberapa desa di Klaten dan Gunung Kidul.

Bagaimana dengan kategori bantuan lain yang dijanjikan pemerintah? Seperti dilansir di mana-mana, Wakil Presiden Yusuf Kalla pernah menjanjikan akan memberi bantuan kepada keluarga korban gempa yang rumahnya mengalami kerusakan akibat gempa - sesuai dengan tingkat kerusakannya. Rencananya, bantuan yang diberikan disesuaikan dengan kategori kerusakan rumah: mulai dari Rp 10 juta untuk rusak ringan, 20 juta untuk rusak sedang, hingga Rp 30 juta rupiah untuk keluarga yang rumahnya rusak berat seperti terjadi di Bantul. Janji ini menimbulkan sejumlah permasalahan yang ternyata tidak diantisipasi oleh pemerintah sebelumnya. Pertama, kategorisasi 'berat-ringan'. Apa kategori rusak ringan? Apa kategori rusak berat? Kalau kategori rusak ringan berarti genteng melorot dan pecah sekitar maksimal 10 biji, seperti saya misalnya, layakkah itu mendapatkan ganti rugi Rp 10 juta? Kalau rumah yang masih berdiri dikategorikan rusak sedang sehingga tak perlu mendapatkan ganti rugi maksimal, fakta lapangan justru memperlihatkan bahwa rumah-rumah yang masih bertembok bukannya cukup aman dihuni. Biarpun tidak runtuh seluruhnya, tembok-tembok yang tersisa pecah-pecah di sana-sini, belah, rekah, tak sekadar retak! Banyak sekali rumah yang masih berdiri, tapi kondisinya 'kopyor' — dari luar kelihatannya utuh, tapi di dalamnya ancur-ancuran. Banyak rumah yang masih berdiri, tapi titik berdirinya sudah bergeser sekian meter-sudah berpindah dari pondasinya sendiri. Siapa berani menjamin keamanan untuk menempatinya? Banyak pula bangunan sekian lantai yang pascagempa berkurang tingginya - satu dua lantai paling bawah, ambles gara-gara gempa. Inilah yang terjadi di gedung ISI di Sewon Bantul-yang rencananya harus diledakkan terlebih dahulu sebelum dibangun kembali. Juga di sejumlah bangunan IAIN Sunan Kalijaga. Rekonstruksi tidak sekadar menambal saja, tapi harus menghancurkan bangunan lama. Layakkah jenis kerusakan seperti ini dikategorikan ringan atau sedang?

Tapi, belum juga terpecahkan masalah ini, sudah timbul masalah baru. Pemerintah pusat kesulitan menalangi dana rekonstruksi yang diperkirakan mencapai 1,24 trilyun rupiah, sehingga daerah diminta membantu. Tentu saja daerah kelabakan - di satu sisi mereka harus membenahi diri, di sisi lain diminta menalangi dana bantuan. Jumlah yang diminta untuk ditalangi pun tak tanggung-tanggung, berkisar 25 persen hingga 40 persen dari total kebutuhan. Bupati Bantul, Drs. Idham Samawi, hanya bisa tersenyum getir-APBD Bantul saja tak sampai 1 trilyun rupiah. Di tengah keterpurukan, bagaimana mungkin pemerintah daerah mampu menalangi dana bantuan yang dijanjikan oleh pemerintah pusat kepada rakyat korban gempa?

Tanda-tanda kebangkitan kini memang terlihat di mana-mana. Korban pascagempa di DIY maupun Jateng, dengan bantuan begitu banyak pihak, tampak mulai menata hidupnya kembali. Tapi, kita tak bisa menutup mata pada kenyataan sesungguhnya. Apa yang disampaikan di atas merupakan sejumlah fakta bencana dan pascagempa yang terjadi di lapangan — setidaknya hingga $\mathrm{H}+40$ gempa...

\section{SCM, Komunikasi, dan Aspek Kultural}

Belajar dari kasus bencana di negara-negara lain, pendekatan yang umum dilakukan untuk menata manajemen penyaluran bantuan berbasis pada konsep supply chain management (SCM), yaitu serangkaian pendekatan yang mengintegrasikan anggota supply chain dalam mendistribusikan produk dengan kuantitas tepat, lokasi yang tepat, waktu yang tepat, untuk memperkecil biaya dan memenuhi kebutuhan sasaran bantuan (Agustini, 2006). Tiga elemen penting SCM meliputi struktur jaringan supply chain, proses supply chain, dan komponen manajemen supply chain. Setiap elemen pada pokoknya harus memiliki identifikasi stakeholder dan tujuan yang jelas, sehingga strategi, rancangan supply chain, maupun implementasi prosesnya dapat diarahkan pada pemenuhan tujuan yang bisa diukur dengan standar-standar yang pasti untuk memastikan evaluasi. Bagaimana menerapkan pendekatan SCM pada kondisi krisis penyaluran pascagempa di DIY dan Jateng? Apa 
sesungguhnya yang terjadi di lapangan? Mari kita telusuri komponen dan faktor-faktornya satu per satu, dimulai dari struktur jaringan supply chain, masalah pendataan, sarana-prasarana komunikasi dan transportasi, serta aspek moral, attitude, dan kultural.

Pertama, struktur jaringan supply chain. Struktur ini menggambarkan jaringan kerja anggota dan hubungan antaranggota. Yang disebut anggota supply chain meliputi semua lembaga atau organisasi yang berhubungan dengan lembaga focal, baik secara langsung maupun tidak langsung (Agustini, 2006). Dalam kondisi bencana, setiap pemerintah memiliki lembaga tersendiri untuk bergerak mengatasi keadaan. SAR, misalnya, difungsikan terutama dalam kondisi-kondisi seperti ini. Di Indonesia, lembaga yang mestinya diposisikan sebagai lembaga focal adalah Satkorlak yang dalam struktur kedinasan berada di bawah Departemen Sosial. Satkorlak sebagai satgas bencana bertugas menjadi pos induk dalam segala sesuatu yang berkaitan dengan bencana: pos informasi, crisis center, induk masterplan strategi mengatasi bencana, titik awal distribusi, pengendali dan pemantau distribusi dan evaluasi, dan lain-lain. Dalam kondisi krisis bencana, semua pihak harus berhubungan langsung dengan Satkorlak-Satkorlak di sini bisa dikatakan menjadi 'presiden' di wilayah bencana. Ia bertugas mengidentifikasi kebutuhan di setiap titik supply chain, mendata bantuan, mendistribusikan, memantau distribusi, dan menindaklanjuti setiap umpanbalik untuk kelangsungan distribusi bantuan — hingga semua kebutuhan dalam jaringan supply chain terpenuhi. Kebutuhan dalam jaringan supply chain berbeda-beda: kebutuhan lembaga focal dan pemberi bantuan terkait dengan informasi data, kebutuhan korban gempa terkati dengan bantuan, kebutuhan satgas distribusi terkait dengan pemetaan-Satkorlak harus memastikan bahwa semua jenis kebutuhan ini terpenuhi.

Apa yang terlihat di lapangan pascagempa, terjadi tidak demikian. Posisi Satkorlak tampak terabaikan - sebagian besar karena Satkorlak dan pemerintah sendiri tidak tahu bagaimana harus memfungsikan badan tersebut. Satkorlak yang semestinya diposisikan sebagai pusat penanggulangan bencana, direduksi fungsinya menjadi sekadar gudang penyaluran bantuan tempat distribusi awal yang kacau balau dilakukan. Maka, alih-alih menyaksikan sebuah pusat informasi beroperasi, kantor Satkorlak ketika itu tampak seperti gudang mie instan dan beras Dolog. Sangat menyedihkan. Andaikata Satkorlak difungsikan maksimal, sesungguhnya tidak perlu seorang presiden sampai harus memindahkan kantornya ke wilayah bencana. Toh, kedatangan presiden, yang dilanjutkan oleh wakil presiden yang memegang langsung posisi kepala Satkorlak, tidak membantu keadaan. Terbukti, penyaluran bantuan masih tetap kacau balau di tengah kehadiran mereka.

Kedua, pendataan. Inti dari kelancaran proses penyaluran bantuan berbasis SCM adalah komunikasi dan informasi. Dua faktor penting ini tak bisa beroperasi tanpa adanya data. Maka, pendataan menjadi titik kritis bagi sistem manajemen krisis ini. Data yang paling diperlukan pada kondisi bencana terkait dengan masalah supply dan demand - bagaimana kondisi situasi, siapa saja korbannya, apa yang diperlukan warga, apa yang mereka minta, semua disesuaikan dengan kondisi lapangan dan kondisi korban. Pendataan tak dilakukan sekali-dua kali, melainkan harus diupdate terus-menerus.

Pendataan menjadi salah satu masalah krusial yang terus-menerus memancing perdebatan tak berkesudahan di antara pemerintah dan lembagalembaga yang (maunya) turut membantu menanggulangi krisis. Ironisnya, masalah debat pendataan ini pula yang menjadi salah satu penyebab macetnya atau lambannya penyaluran bantuan! Pemerintah menghendaki data seakurat mungkin, dengan alasan pendataan penerima bantuan diperlukan bagi kepentingan proses pengauditan bantuan. Pemerintah bertanggungjawab menegakkan proses audit inisebuah alasan yang sangat masuk akal dan bisa dipahami — untuk menjamin akuntabilitas bantuan. Maklum saja, pemerintah menerima dana bantuan (atau janji dana bantuan) yang luarbiasa besarnya dari banyak negara/lembaga yang bersimpati. 
Kalau proses audit tidak dilakukan dengan baik, akuntabilitas tidak terpenuhi. Akibatnya akan berpengaruh pada citra dan posisi pemerintah di dunia internasional. Dalam kerangka ini, kekeraskepalaan pemerintah untuk mengedepankan proses audit bisa dipahami. Dipahami, tapi belum tentu itulah yang paling benar dan paling mendesak dilakukan dalam kondisi krisis.

Di pihak lain, menanti pendataan selesai, dengan proses pendataan konvensional di mana setiap aparat diwajibkan mendatangi korban satu per satu dan mendata mereka secara lengkap, jelas akan memperparah kondisi korban gempa yang memerlukan penanganan segera. Dalam kondisi di mana semua infrastruktur masih berfungsi dengan baik, pendataan saja masih butuh waktu: mengumpulkan petugas pendata, mengidentifikasi data yang harus diambil, menyamakan persepsi ihwal data tersebut, mengevaluasi dan melengkapi data. Bagaimana dengan kondisi bencana di mana seluruh infrastruktur nyaris hancur, seperti terjadi dalam gempa DIY dan Jateng? Ketika perintah pendataan diturunkan, aparat pemerintahan desa dalam keadaan lumpuh total. Banyak aparat turut menjadi korban - tewas atau luka-luka, atau mengalami trauma bencana. Aparat yang bisa bertugas pun tak tahu harus mulai dari manaperintah pendataan datang begitu saja, ketika ditanya apa yang harus didata jawabannya adalah apa saja. Mereka bahkan diultimatum untuk mengumpulkan data dua hari setelah perintah pendataan dikeluarkan! Bisa dibayangkan apa yang terjadi ketika data dilaporkan. Banyak data yang tidak nyambung, banyak data yang harus diterjemahkan ulang, akibatnya menambah kerumitan proses pengolahan data dan memperlambat pengiriman bantuan!

Sementara itu, LSM-LSM yang tidak sabar lalu membentuk posko tersendiri dan melakukan pendataan dengan versinya sendiri. Istilahnya macam-macam, mulai dari pemetaan krisis, pemetaan korban, pemetaan bencana, dsb. Mereka mengerahkan kader-kadernya, merekrut langsung orang-orang di lapangan, menerjunkan personilpersonilnya. Cara ini memang bisa memangkas waktu - tapi karena tanpa koordinasi, masingmasing LSM bergerak sendiri, akibatnya lagi-lagi terjadi inefesiensi dan inefektivitas bantuan. Di tepian jalan utama Bantul, kita bisa melihat begitu banyak LSM mendirikan posko bantuan. Nyaris setiap kilometer berdiri posko-posko LSM anu dan itu, memberikan layanan kesehatan, konseling psikologi, membantu pengadaan dan penyaluran logistik, crisis center (buat anak-anak, buat perempuan, buat lansia, dan lain-lain.) - berjalanjalan sepanjang Bantul laksana melihat 'iklan-iklan' institusi di mana-mana (inikah yang namanya turisme bencana dengan 'iklan' berupa lembaga pemberi bantuan yang berusaha meneguhkan posisi mereka dan menanamkan awareness akan eksistensi mereka di tengah para korban?). Celakanya, pemandangan seperti ini tidak terjadi di lokasi-lokasi bencana lain yang tidak berada di pinggir jalan. Di Kecamatan Berbah, yang ironisnya terletak di belakang Bandara Adisucipto, hanya ada satu dua tenda posko bantuan dari LSM luar. Kebutuhan masyarakat korban gempa jelas tidak bisa terlayani dengan memadai di sini.

Andaikata Satkorlak difungsikan dengan baik, mestinya tidak perlu terjadi kesimpangsiuran dalam pendataan. Satkorlak sebenarnya punya jaringan sampai ke desa-desa. Fungsi pemerintahan kepala desa di dalamnya juga termasuk fungsi-fungsi satkorlak dalam kondisi krisis. Sayangnya, kapasitas ini tidak dibina dengan baik, sehingga ketika bencana terjadi, semua titik yang mestinya berfungsi aktif, menjadi lumpuh. Ihwal metode pendataan yang diributkan sendiri, sebenarnya tidak perlu menjadi persoalan andaikata semua pihak menyadari skala, intensitas bencana, dan parahnya kondisi yang terjadi. Bahkan BPS sendiri, lembaga pendataan nasional, jauh-jauh hari sudah menyatakan, dalam kondisi seperti musibah gempa, di mana semua infrastruktur hancur, tidak perlu berdebat soal metode pendataan. Lakukan pendataan sebisanya dengan melibatkan masyarakat — siapa pun mereka, lurah atau bukan, merekalah yang paling tahu apa yang paling dibutuhkan. Data awal tidak bisa diperoleh dengan cara lain. Data awal inilah yang menjadi start penyusunan peta krisis untuk melakukan proses 
identifikasi selanjutnya. Tidak bisa lain, proses identifikasi mau tidak mau dilakukan secara snowball. Tetapi, apabila dilakukan dengan cepat, dalam arti semua informasi segera dikomunikasikan dan ditindaklanjuti, bantuan dalam didistribusikan dengan cepat. Dalam gempa Yogya dan Jateng, ketika terjadi ribut-ribut proses pendataan antara LSM dan pemerintah, tampak jelas betapa posisi warga setempat sebagai sumber data dan narasumber utama sangat terabaikan.

Ketiga, sarana dan prasarana komunikasi dan transportasi. Dalam proses informasi dan komunikasi, peran teknologi tak dapat dikesampingkan. Sungguh miris rasanya melihat Satkorlak masih menggunakan teknologi handy talkie yang kuno, sementara kalau kita buka internet, LSM-LSM terutama yang didanai oleh pihak luar sudah men-set-up website-website yang melaporkan kondisi mutakhir pascagempa. Blogblog pribadi bahkan bermunculan dalam hitungan hari. Sebuah wahana dunia maya, www.helpjogja.net merupakan salah satu situs yang berperan besar dalam pemetaan awal krisis, sehingga mampu menghubungkan rantai supply dan demand di wilayah bencana dengan segera. Banyak sekali kelompok relawan independen yang memanfaatkan situs ini untuk memfokuskan bantuan mereka. Selain internet, sarana lain yang berfungsi sangat ampuh adalah teknologi telekomunikasi personal. Begitu banyak SMS bertebaran, dikirimkan dari satu nomor ke nomor lain, untuk menyebarluaskan pesan-pesan permohonan bantuan. Banyak sekali pihak yang terbantu dengan cara ini. Tapi jalur ini rawan sekali dengan penipuan. Kini mulai banyak terungkap aksi tipu-tipu lewat SMS berkedok pemberian bantuan. Andai saja pusat informasi gempa dipusatkan pada satu lembaga focal, katakanlah Satkorlak, tentu kejadian seperti ini bisa ditanggulangi.

Tetapi, dalam kondisi bencana seperti Yogya dan DIY, tidak cukup hanya memfungsikan teknologi informasi dan telekomunikasi canggih sebagai sarana komunikasi. Teknologi telekomunikasi sesungguhnya baru bisa berfungsi kalau infrastrukturnya utuh. Masalahnya, dalam kondisi gempa lalu, seluruh infrastruktur lumpuh tak berfungsi. Menara RBS runtuh, tiang telepon berloncatan hingga memutuskan kabel-kabelnya, listrik padam berminggu-minggu-jika hanya mengandalkan teknologi, proses informasi dan komunikasi pasti akan terganggu. Maka, gunakan semua cara yang memungkinkan. Salah satunya dengan menggunakan radio komunitas dan jejaring komunikasi informal antarwarga. Pada jam-jam awal bencana terjadi, peran radio tak bisa dikesampingkan. Listrik padam, televisi tak bisa dinyalakan, kalaupun ada berita, perkembangannya lambat sekali. Radio-lah sang pahlawan ketika itu. Jejaring komunikasi informal antarwarga bila diaktifkan juga bisa menjadi rantai komunikasi yang sangat penting. Sejumlah relawan memanfaatkan petani-petani binaan masing-masing di desa-desa wilayah bencana sebagai rantai terdepan untuk mendapatkan informasi akurat dan mendekati lokasi-lokasi bencana.

Transportasi menjadi titik krusial dalam proses distribusi. Namun, dalam kasus gempa Yogya dan DIY, masalah transportasi tidaklah separah yang terjadi dalam bencana tsunami di Aceh. Jalan-jalan relatif masih utuh. Kalau pun ada keterlambatan bantuan mencapai lokasi-lokasi terpencil seperti pedesaan di Gunung Kidul, Wonosari, dan Kulon Progo, itu lebih disebabkan keterlambatan penerimaan data.

Keempat, aspek attitude, moral, dan kultural. Seperti diungkapkan oleh Agustini dalam artikelnya di Harian Pikiran Rakyat berjudul "Pentingnya Integrasi dan Koordinasi” di penghujung awal Juni 2006, keberhasilan SCM tidak saja bergantung pada jejaring yang terkoordinasi dengan baik, tetapi juga pada aspek kepemimpinan, budaya organisasi, dan nilai baik serta keikhlasan untuk saling memercayai antaranggota supply chain. Apa yang terjadi dalam kasus gempa Yogya dan Jateng?

Pertama, aspek kepemimpinan. Dalam jalur administrasi republik, ketika presiden memindah kantornya ke Yogya, otomatis mestinya jalur administrasi daerah pun berkiblat ke Presiden sebagai RI-1. Tapi, logika semacam ini tidak berlaku di Yogya. Dalam budaya Yogya, konstelasi kepemimpinan berada di tangan Sultan sebagai 
penguasa formal ataupun spiritual. Fakta ini sudah terinternalisasi sedemikian dalam-Ngarso Dalem adalah posisi yang tidak tergantikan oleh siapa pun. Bisa dibayangkan apa yang terjadi ketika presiden dan aparatnya datang mengambilalih. Perintah presiden dikeluarkan, tapi pelaksananya di lapisan bawah kebingungan. Apa yang harus mereka lakukan dalam situasi ini? Mereka bisa bertanya dan minta apa saja pada Sultan, tapi kepada Presiden, harus bagaimana? Siapa memerintah siapa? Dalam kondisi serba bingung dan vakum seperti ini, sampai muncul sebuah anekdot, mestinya, kalau presiden mau main perintah di Yogyakarta, bawa dong sekalian bawahan-bawahannya. Kepekaan budaya seperti ini sangat diperlukan dalam kondisi krisis. Itulah pelajaran penting yang bisa diambil dalam kasus ini.

Kedua, budaya organisasi. Lagi-lagi, ini masalah kepekaan. Budaya organisasi Yogya adalah budaya masyarakat monarki berbasis agrikultur yang masih memegang teguh posisiposisi istimewa para pemimpin kultural dan spiritualnya. Tindakan memotong jalur kuasa Sultan, benar-benar tak termaafkan. Dalam kasus Merapi, lihat betapa dominannya posisi seorang juru kunci, Mbah Maridjan. Sentral organisasi komunitas dalam budaya organisasi masyarakat DIY/Jawa Tengah tidak sepenuhnya berada pada personil kelurahan atau aparat pemerintahan, tapi lebih pada tokoh-tokoh kultural semacam itu: juru kunci, den bei, mbak Yayuk atau Pak Kusumo yang menjadi tokoh-tokoh paranormal setempat, kepalakepala kelompok tani binaan ... mestinya, mereka juga dilibatkan sebagai keyperson dalam rantai distribusi, informasi, dan komunikasi.

Ketiga, moral attitude. Pada niat baik dan keikhlasan untuk saling mempercayai antaranggota supply chain. Tidak mudah mengukur dan menumbuhkan ini. Tapi, apabila lembaga focal dalam struktur jaringan supply chain punya integritas tinggi, pasti posisinya akan disegani dan struktur lain di bawahnya tidak akan berani macam-macam. Ini bukan semata-mata masalah pencitraan lembaga seperti Satkorlak (kalau mau dijadikan focal point), tetapi masalah integritas. Integritas tidak mudah dibangun, tapi bisa diawali dari sosok-sosok kepemimpinan yang memperlihatkan teladan, kejujuran, dan kepedulian pada sesama. Di sinilah, lagi-lagi, kepekaan penghormatan terhadap budaya setempat sangat diperlukan. Karena itu, sempat menjadi pertanyaan bagi penulis, mengapa tidak sejak awal saja Sultan diposisikan sebagai Kepala Satkorlak? Lepas dari apa pun pendapat kita mengenai dia (Sultan juga manusia!), tetap saja kita tak bisa menafikan betapa sentralnya dan betapa disegani sosok seorang Sultan-sehingga ia juga begitu menjaga perilakunya kepada masyarakatnya yang menghamba padanya.

Moral attitude ini juga penting untuk menjadi tertib perilaku para 'relawan' yang bermunculan di wilayah bencana. Di satu sisi, bantuan para relawan sangat dibutuhkan, tapi di sisi lain, ketidakpekaan terhadap budaya setempat (di samping motivasi pribadi) mengacaukan niat baik yang menyertai setiap bantuan. Sebuah organisasi motor besar, yang anggotanya adalah tokoh-tokoh signifikanpejabat dan jelas orang-orang kaya, datang bermaksud memberi bantuan langsung ke lokasi bencana. Di tengah derita para korban gempa yang harta bendanya musnah, kelompok motor besar ini datang beriring-iringan menggunakan voorijder, dengan lampu berkelap-kelip dan motor yang kinclong, pengendaranya tentu tak kalah kinclong mengenakan segala macam atribut organisasi kebanggaannya. Sungguh sangat kontras dengan kondisi korban di lokasi bencana. Sikap seperti ini sangat menyesakkan, hingga akhirnya memunculkan pertanyaan, mau membantu, atau mau pamer? Mau membantu, kok malah menyusahkan orang lain? Bayangkan saja, berapa banyak kendaraan yang dipaksa 'minggir' demi memuluskan jalur mereka? Padahal, banyak di antara kendaraan tersebut adalah truk-truk relawan penduduk desa lain yang ramai-ramai datang untuk menyumbangkan tenaga membereskan lokasi bencana. Keesokan harinya, terpampang foto mereka besar-besar di sejumlah media nasional, bahkan muncul di televisi pada jam-jam penting: organisasi anu menjadi relawan di lokasi bencana dengan mengadakan aksi solidaritas kemanusiaan. Solidaritas kemanusiaan itu diwujudkan dalam 
pemberitan bantuan. Foto seremonial penyerahan bantuan dari 'relawan' pada pak Dukuh yang lusuh dan kumuh mewakili ‘korban'-lengkap dengan spanduk besar. Yang menyakitkan hati, di antara foto-foto yang terpampang, termuat pula foto sejumlah 'relawan istimewa' bergaya mengacungkan tanda $\mathrm{V}$ (victory) dengan jarijarinya di atas reruntuhan gempa. Apanya yang mesti disoraki? Kemenangan atas apa? Yang terlihat adalah ekspresi riang gembira di atas penderitaan orang lain. Kontan saja, keesokan harinya, di lokasi bencana bermunculan papan bertuliskan: foto-foto $\$ 2$, souvenir \$1/bata. Sebuah sindiran dengan plesetan khas gaya Yogya untuk 'relawan-relawan' yang datang jauh-jauh ke Yogya untuk melakukan perjalanan yang lebih tepat disebut sebagai 'turisme bencana,' alih-alih aksi simpati dan solidaritas. Menyedihkan, memuakkan, tapi inilah gambaran attitude yang dibangun atas ketidakpekaan terhadap penderitaan sesamanya, ketidakpekaan budaya lokal.

Andaikan, ada lembaga focal yang dihormati integritasnya, tentu hal seperti ini tidak perlu terjadi. Kita tidak bisa menyalahkan pihak-pihak yang ingin menyalurkan bantuan langsung ke lapangan karena kenyataannya tidak ada atau sedikit sekali lembaga yang bisa dipercaya akuntabilitasnya dalam distribusi bantuan. Di sisi lain, ketika aktivitas penyaluran bantuan berlangsung seperti ini, terjadi ekses-ekses yang tak dapat dihindari, seperti kasus 'pamer jaya' tadi.

Demikianlah beberapa faktor penting yang bisa dievaluasi dari aksi penyaluran bantuan di Yogya dengan pendekatan krisis berbasis SCM.

\section{Rekomendasi}

Krisis penyaluran bantuan dalam kasus gempa DIY dan Jateng membuka mata kita ihwal pentingnya manajemen sistem informasi di masa krisis. Apa yang terjadi di lapangan, pada hakekatnya, bisa dipandang sebagai kekacauan atau bahkan ketiadaan manajemen sistem informasi di masa krisis. Dalam kondisi 'normal', manajemen sistem informasi bisa dilakukan dengan berbagai pendekatan. Tetapi, bagaimana manajemen sistem informasi di masa krisis, ketika seluruh infrastruktur tumbang? Inilah yang perlu dipikirkan dan ditata sejak sekarang, untuk mengantisipasi musibah bencana yang walau tak pernah diharapkan, namun tak dapat diprediksi kejadiannya.

Apabila diperhatikan secara seksama, titik kritis keberhasilan pendekatan SCM bertumpu pada masalah komunikasi dan informasi: integrasi dan koordinasi tidak akan tercapai jika informasi tidak dikomunikasikan dengan baik. Komunikasi informasi merupakan faktor yang menyatukan setiap komponen SCM. Tanpa komunikasi dan informasi, setiap bagian SCM akan berjalan sendirisendiri-sehingga memunculkan kesia-siaan yang terjadi di lapangan. Kasus Gempa Yogya dan Jawa Tengah bisa dijadikan momentum studi kasus yang komprehensif, khususnya bagi pakar-pakar komunikasi dan manajemen, untuk memberikan alternatif manajemen krisis yang cepat tanggap.

Di sisi lain, belajar dari musibah ini, kita bisa melihat betapa krusialnya peran warga apabila difungsikan secara maksimal. Dalam wacana seputar penyaluran bantuan pascagempa, warga selalu diposisikan sebagai korban yang pasif dan tidak berdaya. Peran warga lokal yang bukan korban juga dikesampingkan — seolah mereka tidak berarti apa-apa. Ini anggapan yang sangat keliru. Sesungguhnya, warga lokal punya andil sangat besar, terutama pada masa awal pascagempa. Melalui jaringan komunitas, warga lokal secara mandiri berhasil memobilisasi bantuan kepada korban pasacagemba di minggu-minggu survival. Adalah warga lokal yang mendirikan dapur umum pertama kali, mengusahakan logistik dan obatobatan dari kantong mereka sendiri, dan mengupayakan fasilitas-fasilitas primer penunjang hidup bagi korban pascagempa seperti tenda dan pakaian. Pendataan yang dilakukan mungkin tanpa sistem, snowball saja, tapi berkat jejaring komunitas yang kuat, informasi supply dan demand bisa didapatkan dan ditindaklanjuti dengan cepat. Pemerintah maupun lembaga bantuan apapun mestinya belajar dari mereka, dan memanfaatkan keberadaan mereka dalam manajemen krisis bencana. Lebih dari itu, pendekatan apapun yang akan dirumuskan untuk menata manajemen krisis bencana, hendaknya 
Terakreditasi Dirjen Dikti SK No. 56/DIKTI/Kep/2005

diaplikasikan dengan mengutamakan pendekatan kepada warga lokal melalui civic management.

\section{Daftar Pustaka}

Agustini, Prima Mulyasari. 2006. "Pentingnya Integrasi dan Koordinasi”. Artikel dalam HU Pikiran Rakyat, tanggal 1 Juni.
Astuti, Santi Indra. 2006. "Manajemen Krisis Ala Rakyat”. Artikel dalam HU Kompas, tanggal 6 Juni.

Astuti, Santi Indra. 2006. "Bencana, Wujud Penderitaan nan Agung”. Artikel dalam HU Kompas tanggal 18 Juni. 
